Western University

Scholarship@Western

Aboriginal Policy Research Consortium International (APRCi)

2003

\title{
Aboriginal/indigenous citizenship: an introduction
}

Patricia K. Wood

York University

Follow this and additional works at: https://ir.lib.uwo.ca/aprci

Part of the Politics and Social Change Commons

Citation of this paper:

Wood, Patricia K., "Aboriginal/indigenous citizenship: an introduction" (2003). Aboriginal Policy Research Consortium International (APRCi). 432.

https://ir.lib.uwo.ca/aprci/432 
This article was downloaded by: [University of Western Ontario]

On: 09 December 2012, At: 07:13

Publisher: Routledge

Informa Ltd Registered in England and Wales Registered Number: 1072954 Registered

office: Mortimer House, 37-41 Mortimer Street, London W1T 3J H, UK

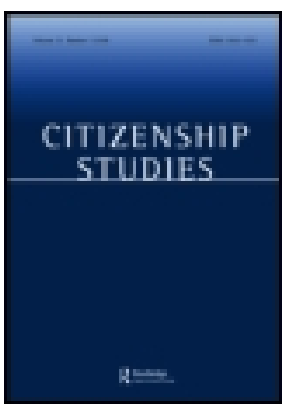

\section{Citizenship Studies}

Publication details, including instructions for authors and subscription information:

http:// www.tandfonline.com/ loi/ ccst20

\section{Aboriginal/indigenous citizenship: an introduction}

Patricia K. Wood

Version of record first published: 03 J un 2010.

To cite this article: Patricia K. Wood (2003): Aboriginal/indigenous citizenship: an introduction, Citizenship Studies, 7:4, 371-378

To link to this article: http:// dx. doi.org/ 10.1080/1362102032000134930

\section{PLEASE SCROLL DOWN FOR ARTICLE}

Full terms and conditions of use: http://www.tandfonline.com/page/terms-and-conditions

This article may be used for research, teaching, and private study purposes. Any substantial or systematic reproduction, redistribution, reselling, loan, sub-licensing, systematic supply, or distribution in any form to anyone is expressly forbidden.

The publisher does not give any warranty express or implied or make any representation that the contents will be complete or accurate or up to date. The accuracy of any instructions, formulae, and drug doses should be independently verified with primary sources. The publisher shall not be liable for any loss, actions, claims, proceedings, demand, or costs or damages whatsoever or howsoever caused arising directly or indirectly in connection with or arising out of the use of this material. 


\title{
Aboriginal/Indigenous Citizenship: An Introduction
}

\author{
PATRICIA K. WOOD
}

Citizenship has emerged in the last decade or so as a key concept in the debates regarding social justice, particularly with respect to minorities. It encompasses theory and practice, and addresses the many aspects of 'belonging' to a nation, from the strictly legal and formal, to the everyday, ordinary and abstract. Nowhere is its usage more appropriate than for Aboriginal peoples, whose positions vis-à-vis the state conflate political, social, economic and cultural rights. Historic and present relations between the state and Aboriginal peoples in many places reveal agendas of extreme control over every aspect of their lives. Efforts to dispossess Aboriginal peoples of their land were intimately linked to discourses of difference and inferiority. In many instances, the state had as its explicit goal the extermination of Aboriginal languages, social customs, spiritual beliefs, political structures, land and other property rights, and even the extinction of the peoples themselves. By definition, the politics of Aboriginal identity, culture and citizenship complicates the idea of citizenship in postcolonial societies, often challenging the basis of the very existence of the nation-state. As revisionist histories have revealed and widened the cracks in homogenizing narratives, Aboriginal voices have been among the most insistent in the calls to reconstitute the social and political contracts that frame modern democracies.

Language itself presents so many opportunities to contemplate the complexity of the situation. The term 'Indian', still in common use in parts of the Americas, refers to the original hope of Columbus that he had reached India. In Australia, the term 'Aborigine' is most common among non-Aboriginals. However, Torres Strait Islanders refer to themselves separately with this reference to their specific geography, and throughout the country, Aboriginal peoples have adopted, on a regional basis, a word from local languages, usually meaning 'person', such as koori, common in New South Wales. In this part of the world, there appears to be a slow and gradual move towards the use of specific names of groups, tribes or nations, in Aboriginal languages, perhaps exemplified by the Maori in New Zealand/Aotearoa or the Ainu in Japan. In Australia, the word 'black' is also used to describe Aboriginals; this term only refers to Africans in the Americas. In Canada, the term 'First Nations' directly addresses and challenges the 'Two Founding Nations' political mythology of the creation of Canada, and emphasizes the political organization and sovereignty of the peoples who inhabited North America before colonizers arrived. 'Native' (with a capital ' $N$ ' here for

Patricia K. Wood, Department of Geography, N430 Ross Building, York University, Toronto, ON M3J 1P3, Canada; e-mail: pwood@yorku.ca 
distinction) is part of a similar set of categories between those who were born outside a given country ('immigrants'), those born there ('native'), and those claiming a collective, historical birth ('Native') preceding the colonial era. This last distinction is highly indicative of an aspect inherent but sometimes less obvious in other terms: that 'Aboriginal' (or Indian, or Native, and so on) is a historically and geographically constituted category and, indeed, an equally constructed identity.

This nomenclature reveals the ways in which history is embedded in language. Some of these terms indicate movement towards recognition of a specific history in a positive manner; others reflect only the historical disregard of Indigenous peoples and their claims. All provide evidence of negotiation with, and even challenges to, existing nationalist narratives, as particular terms wax and wane in their usage. As will be seen again below, these linguistic maneuvers possess implications for citizenship. Naming is fundamental to self-definition and the terms of reference to subsequent recognition. Even more significantly, the discourses that surround and sustain these terms have been generated partially through state policy, and, in turn, reflexively construct the ideological architecture within which policy is framed.

Often confused or conflated with racial and ethnic classifications (as some of the papers here discuss), Aboriginals identify with distinct groups as a result of their pre-colonial and postcolonial histories and geographies, which included the disruptions/innovations of relocation and intermarriage well before the new colonials. Although there are parallels and overlaps with the rights struggles of diasporic minorities, Aboriginal peoples present different challenges to the nation-state and to globalization. Of course, all categories are historically and geographically contingent, rather than essential, abstract identities. This is not to say merely that a given identity is specific to its time and place, but that, as Marx noted, we make our choices within the frameworks we have inherited. It is time and place that construct the identities in the first place; it is the social and material conditions that generate the group and the group's consciousness. The links in this 'production process' generate the durability of identities as well as their flexibility and fluidity-although there is not space here to explore this question beyond the case of Aboriginal peoples.

Aboriginal makes reference to time, indigenous to place. Both terms connote an idea of ancient and of durability, in contrast and often as a challenge to a modern world of mobility and innovation. The very idea that people might stay where they are for millennia is positively antediluvian to those whose global mobility is practiced on a daily basis. With that mobility comes change: human and physical landscapes have been altered on a monumental scale in the past 500 years, and the pace and scope of change show little sign of abating in this 'globalized' era. Citizenship studies, by and large, have responded and often raised an alarm with regard to the challenges of globalization: how does the increased flow of people, capital and information affect meaning and practice of citizenship? John Urry has observed that from 1989 forward, 'The struggles for citizenship ... were increasingly globalised', and there are subsequent 'modes of social experience that transcend each nation-state and its constitution of the national citizen' (Urry, 1999, pp. 310-1). Directly and indirectly, mobility is 
producing challenges to and new forms of citizenship. Both advocates of a global or cosmopolitan citizenship (Urry, 1990, 1999; Held, 1995, 1999; Archibugi et al., 1998; Linklater, 1998; Falk, 2002) and critics (Touraine, 1997; Miller, 2000) attribute debates over the meaning and practice of citizenship to the increase in volume and speed of global flows.

Cosmopolitan citizenship, with its roots working back to trade and migration in the fifteenth century, today challenges the "concept of citizenship [which] has been based upon the notion of the bounded society' (Urry, 1999, p. 311; Miller, 2000) This assertion, however, is somewhat misleading, as the bounded societies to which these scholars refer, that is, modern nation-states, were themselves the products of great mobility and flows. First, in the case of exploration and imperialism, whether over land or sea, the capacity for moving goods and people, from settlers with their non-indigenous species to armies and their armaments, was key to their success. Once settler governments were established, the domestic projects to facilitate mobility were just as crucial, particularly of national railroads, as engines of literal and metaphorical nation-building. In all of these projects may be found the desire to conquer geography, to not be bound by its physical inconveniences of distance, slope, and climate. For all the attachment to place (and ownership of it) encouraged by patriotic, nationalist campaigns, there has been an equal drive to transcend the land rather than be in communion with it. That there might presently be an idea of a citizenship rooted in the 'space' of networks of cities or enormous transnational regions is not very different, from an Aboriginal perspective, from the idea that Aboriginal peoples speaking more than 250 languages be merged into the single unit of colonial Australia or that 'Blackfoot Country' be divided by the Canadian-American border.

This is the continuity between the pre-industrial era and the industrial/post-industrial/global eras, none of whose conceptions of citizenship have served well those whose attachment to the land was powerful indeed. For many Indigenous peoples, there is a great deal of unfinished business from colonial periods, in that the parties have yet to reach mutually satisfactory agreements on such fundamental questions as land and governance. As in so many other cases of historical injustices, the state and its settlers moved on without addressing the damage wrought by previous actions. Instead of reconciliation, more often accusations are offered: Why can't they just take care of themselves? Why do they live in the past? It is a challenge to Aboriginal communities and scholars alike (greatly assisted by more of the former also joining the latter) to find a framework of citizenship in the global, cosmopolitan era that is meaningful to Aboriginals and still recognizes their priorities. It is clear from the papers here that linear, post-political models will not satisfy. As Elizabeth Elbourne argues from her opening statement in these pages, 'To study aboriginal citizenship, whether in the colonial or the postcolonial state, is to raise the issue of history'. We cannot assume all stakeholders are in a condition of full citizenship, able to negotiate and participate as they choose in their respective national society or global economy. History teaches us that the present political and economic structures of the world are predicated on the exploitation and subjugation (and worse) of Native people. 
A final irony of this discussion of mobility is the difficulties that arise when Aboriginal people themselves decide to reassert their own mobility, which was often severely restricted by colonizers. Public policy in many places, such as Canada, simply has not provided for the possibility of Aboriginal people leaving their reserves. Public policy, or lack thereof, on the question of mobility is intrinsically linked to the discourse around naming Aboriginal peoples. When employed by non-Aboriginal people, the term 'Native' (and, perhaps to a lesser degree, Aboriginal and Indigenous) has often contained the idea of inhabiting nature and a consequent 'naturalness' in their connection to the land that is explicitly primitive. The construction of their 'authentic' identity is rooted in the idea that the places to which they are indigenous constitute the only places appropriate for them, and thus they are effectively 'incarcerated, or confined, in those places' (Appadurai, 1988, p. 37; Goldie, 1989; Peters, 1996). Similarly, in Western thought, the alleged primitivism of their attachment to the earth has presupposed a specific inability to inhabit the city, even an inherent contradiction in 'Aboriginal' and 'urban' (Peters, 1996). Although both the attachment to the land and the desire to move are fundamental aspects of citizenship (for anyone), neither has been respected. Even when such discursive tensions are resolved, Roger Maaka has demonstrated that urban space, far from being outside the 'natural' world of Aboriginal peoples, remains deeply embedded in their political geography: the reconstitution of one group as a tribe in a metropolitan setting, while improving its social and political cohesion, conflicted with the standing territorial claim of another tribe (Maaka, 1994). The complexities of these geographies are not reflected in public policy.

Within the broad field of citizenship studies, the literature on Native peoples remains relatively small, although it has experienced resurgence in the past few years. The division of scholars working on Native issues into a variety of disciplines often frustrates easy collaboration among them. In addition, there are few opportunities for these scholars to compare their work at the international level. Recent publications such as Paul Havemann's Indigenous Peoples' Rights in Australia, Canada, and New Zealand (1999) and Duncan Ivison, Paul Patton and Will Sanders' Political Theory and the Rights of Indigenous Peoples (2000) indicate, however, that it is quite fruitful to do so.

The idea for this issue began with a conversation with David Wilkins, Lumbee and Associate Professor of American Indian Studies, Political Science and Law at the University of Minnesota. I met David while he was a visiting Fulbright Chair and I was on sabbatical at the Calgary Institute for the Humanities, both at the University of Calgary. It was David's work on the constitutional blurriness of the citizenship status of Aboriginals in the United States, a 'shape shifter' as he appropriately terms it, that encouraged me to bring together a group of scholars from a variety of disciplines with research concerning different countries and time periods in order to compare and contrast the histories, struggles, even the very meanings of Aboriginal citizenship. Indeed, the latter term itself is problematic - there is citizenship within the Aboriginal nation (and 'citizenship' is a word some nations employ) and there is citizenship within the modern nation-state that has claimed jurisdiction over the former. Discriminatory stereotypes and practices against Aboriginal peoples exist globally and their en- 
during nature, their ability to adjust to changing social, economic and political conditions, is startling. Yet the categories and frameworks of exclusion are still so fragile in their uncertainty, so vulnerable to criticism in their violence.

The authors of the papers here were trained in and/or teach in a range of disciplines: anthropology, sociology, geography, history, law, political science, environmental studies and planning. The geographic areas of research are equally varied, including Brazil, Canada, South Africa, Australia and Japan. Although their topics are diverse, there are three central concerns emerging from the pieces when taken in the collective: (1) the common discourses and strategies employed by postcolonial governments in their efforts to control and contain Native peoples, (2) the diverse strategies employed in turn by Native peoples as they seek to reassert their sovereignty over territory, governance and culture, and the effect of these on the identity politics of the nation-state in question, and (3) the tensions between liberal democratic theory/ideology and practice when faced with the political, social and cultural differences and the historical weight of the challenge of Aboriginal citizenship. While the contributions here attest to the diversity of experience in these case studies, in each case, the colonial history and emerging postcolonial present are set in a similar context: the imperial conquerors never left.

All the papers here reveal Indigenous peoples' skill at adaptation. For all any group's longevity in a particular region, their histories, geographies and subsequent identities are far from 'frozen', even prior to the arrival of colonizing powers (Borrows, 1998). Even as many groups seek to distance themselves from the industrial (or post-industrial) societies that surround them, none makes such a choice in oblivion. More often than not, they seek a balance between the opportunities for their communities and the preservation of their languages and cultural practices. Many have openly participated in large commercial ventures, in partnership with governments and private corporations. Our sensitivity to history must not leave Aboriginals relegated to the past. But to move from where we are, we must recognize how we came to stand here.

We must also appreciate that the situations under investigation here are not merely battles of wills, a fight between two sides with clear positions. As Wilkins, among others, has shown (Wilkins, 2001; Wilkins and Lomawaima, 2001), the postcolonial state has yet to figure out its side of things with any definition. In the United States, Supreme Court decisions even appear to contradict each other in their rulings on the governance and jurisdiction of Aboriginal peoples. The situation remains in flux: where there were treaties, their meaning is contested (for example, Treaty 7 Elders et al., 1996); where there were no treaties, the political landscape is no less settled, as Indigenous peoples continue to assert their claims to be who they are and where they are (or would like to be).

In her historical study of the Khoekhoe, Elizabeth Elbourne demonstrates the complexity and instability of identities and categories of citizenship. Destroying any idea that there has been a neat linear progress towards social justice, she identifies 1828 as a highpoint in South African citizenship prior to the postapartheid period. Similarly, in her sweeping historical coverage of policy towards Indigenous people in Brazil, Alcida Ramos demonstrates the varying 
strategies that were employed, at times with little logic, much less linear continuity. David Mercer has identified a comparable ebb and flow of gains for Aboriginals in Australia: legal gains are undermined politically; increased acceptance on the one hand is met with a rise in racism on the other. In these regions where little or no claim to the land was ever recognized, Aboriginal peoples are fighting material and political battles for social justice in societies in which they have almost no standing.

Richard Siddle's work on Japan and Patricia Wood's on Canada focus on some contemporary issues-one local, one national - that demonstrate the ways in which the history of Native/non-Native relations resonates in the present and how discriminatory ideologies are reasserted in current policies and practices, including those of 'recognition'. Siddle's research on the Ainu further compels us to compare the Japanese Empire and the practices of the modern Japanese state with those of the West. Siddle notes (in this issue) that physical characteristics of the Ainu are among the discriminatory identifiers employed by the Japanese. Given the centrality of racial discourses to Western imperialisms, particularly the supremacy of 'whiteness', the juxtaposition of these with Japanese discourses and practices ought to infuse the study of empire with new insight, particularly in Asia-Western relations and within the Pacific realm.

In both cases, the state, locally and federally, (still) relies on particular strategies of inclusion/exclusion that privilege political, social and cultural stability, even as the situation they perpetuate is not sustainable, in light of injustice and Native resistance. Underlying these state actions is an unspoken fear of a model of society that would give voice to the past. This careful denial of history reveals not its irrelevance to the present as its practitioners might suggest, but its very power in defining identity and political legitimacy. The state tells particular stories through its policies, narratives that implicitly justify its authority and the political history that produced it. Like the state, Aboriginals seek to participate in the shaping of what stories are told, to claim publicly their identity and know that other recognize their legitimacy. This quest for citizenship exists at all levels: from the desire to be endowed with political rights to the fight against the appropriation and degradation of their identities by non-Aboriginal populations (see Churchill, 1994).

Gordon Christie's work on the constitutional status of Aboriginal peoples in Canada suggests an innovative strategy for proceeding. According to Christie, critical interpretations of the constitution could address unresolved matters of Aboriginal citizenship status within Canada and go a long way towards strengthening their communities as well. The symbiotic nature of this argument demonstrates the potential for renewal, not recidivism, and for growth, not entrenchment. The idea that the two goals are not mutually exclusive but rather mutually supportive questions the stability of homogeneous, assimilative nationalisms achieved through the denial of history and geography.

Throughout these papers, there are two distinct, yet related issues of sovereignty: the first is the request for recognition as a sovereign people, with the right to self-governance within the group; the second is the desire to be sovereign over a place. It is difficult to say which is the greater challenge to the modern nation-state. 
Work on Aboriginal citizenship brings insight to other research in citizenship studies as well. Aboriginals are not the only groups wrestling against the denial of history and geography. Their efforts to reconstitute the state as post-national, but not post-political, articulate a politics of difference to which many other groups can relate, such as immigrants and refugees, who sustain matrices of identity across multiple places and times in ways that challenge the meaning of national borders, reorder narratives of national identity and question the legitimacy of political regimes that rendered residency untenable, or women, who move into paid employment and away from volunteer caregiving labour, express the desire for greater reproductive rights, and articulate a new conception of public and private spheres and the social role of the state. All their struggles draw our attention to fundamental connections between identity and citizenship, to the technologies of power and control, and to the continuing tensions between the rhetoric and practice of liberal democracies as we examine more closely the material and discursive underpinnings of political practices and the construction of citizenship.

\section{References}

Appadurai, A. (1988) 'Putting hierarchy in its place', Cultural Anthropology, 3(1), pp. 36-49.

Archibugi, D. et al. (Eds) (1998) Re-imagining Political Community: Studies in Cosmopolitan Democracy (Stanford, Stanford University Press).

Borrows, J. (1998) 'Frozen rights in Canada: constitutional interpretation and the trickster', American Indian Law Review, 22(1), pp. 37-64.

Churchill, W. (1994) Indians Are Us? Culture and Genocide in Native North America (Toronto, Between the Lines).

Falk, R. (2002) 'An emergent matrix of citizenship: complex, uneven, and fluid', in: N. Dower and J. Williams (Eds), Global Citizenship: A Critical Reader (Edinburgh, Edinburgh University Press), pp. 15-29.

Goldie, T. (1989) Fear and Temptation: The Image of the Indigene in Canadian, Austrialian, and New Zealand Literature (Kingston and Montreal, McGill-Queen's University Press).

Havemann, P. (Ed.) (1999) Indigenous Peoples' Rights in Australia, Canada, and New Zealand (New York, Oxford University Press).

Held, D. (1995) Democracy and the Global Order: From the Modern State to Cosmopolitan Governance (Stanford, Stanford University Press).

Held, D. (1999) 'The transformation of political community: rethinking democracy in the context of globalization', in: I. Shapiro and Casiano Hacker-Cordon (Eds), Democracy's Edges (Cambridge, Cambridge University Press), pp. 84-111.

Ivison, D., Patton, P. and Sanders, W. (Eds) (2000) Political Theory and the Rights of Indigenous Peoples (Cambridge, Cambridge University Press).

Linklater, A. (1998) 'Cosmopolitan citizenship', Citizenship Studies, 2, pp. 23-41.

Maaka, R. (1994) 'The new tribe: conflicts and continuities in the social organization of Urban Maori', Contemporary Pacific, 6(2), pp. 311-36.

Miller, D. (2000) Citizenship and National Identity (Cambridge, Polity Press).

Peters, E. (1996) “"Urban” and "Aboriginal”: an impossible contradiction', in: J. Caulfield and L. Peake (Eds), City Lives \& City Forms: Critical Research and Canadian Urbanism (Toronto, University of Toronto Press), pp. 47-62.

Touraine, A. (1997) What is Democracy? (Boulder, CO, Westview).

Treaty 7 Elders et al. (1996) The True Spirit and Original Intent of Treaty 7 (Montreal and Kingston, McGill-Queen's University Press).

Urry, J. (1990) The Tourist Gaze (London, Sage).

Urry, J. (1999) 'Globalization and citizenship', Journal of World-Systems Research, V(2), pp. 311-24. 
Wilkins, D.E. (2001) 'The manipulation of indigenous status: the federal government as shape shifter', Stanford Law \& Policy Review, 12(2), pp. 223-35.

Wilkins, D.E. and Lomawaima, K.T. (2001) Uneven Ground: American Indian Sovereignty and Federal Law (Norman, OK, University of Oklahoma Press). 